\title{
МАНАСТИР ХИЛАНДАР КАО РАСАДНИК КУЛТУРЕ МЕЪУ ПРАВОСЛАВНИМ СЛОВЕНСКИМ НАРОДИМА
}

Духовна делатност чувеног српског светогорског светилишта, манастира Хиландара, нераздвојно је повезана са универзалним деловањем свеукупне Свете Горе, те јединствене монашке републике православног света. Јер ако је више православних народа имало на Светој Гори своја национална духовна уточишта, ипак је у светогорским манастирима постојао један заједнички православни дух а да национални никада није био прекидан или нестајао. Светогорски манастири су током читавог средњег века, а и у новије доба, били богато обдаривани од православних владара и велможа без обзира на националну припадност њихових ктитора. Стефан Немања је дао знатну материјалну помоћ грчком манастиру Ватопеду, Ђурађ Бранковић је помагао Есфигмен, цар Душан је материјално помагао руски манастир св. Пантелејмона, чији је и други ктитор био, а такође и Есфигмен и још неке друге несрпске манастире на Светој Гори. Наш Хиландар у периоду када се и он и цела Света Гора налазио под турским игом био је често материјално помаган од православних великаша из земаља које су мање биле изложене турском феудалном експлоатисању, о чему сведоче многобројне повеље које се чувају у манастирској библиотеци.

Света Гора, омање полуострво знатно већег Халкидика, као да је створено за тиховање, умне духовне медитације и за дубоку скоро ничим (не)ремећену побожност. Тешко приступачна, ван утврђених морских и сувоземних путева, од којих су први условљени готово увек узнемиреним и узбурканим Егејским морем, Света Гора је својим тамом обавијеним почецима духовности могла да монашким становницима да̂ онај њима толико потребан мир на који су их упућивали први хришћански анахорети. Тај географски доста скучени простор требало је, према замисли светогорских оснивача, да задовољи потребе за усамљеношћу горљивих присталица хришћана IX века, непосредно после иконокла- 
стичких борби које су из темеља потресле тада моћно Ромејско царство. Право устоличење ове својеврсне монашке републике почиње подизањем лавре св. Атанасија 963. г. ${ }^{1}$ После тога убрзо на Светој Гори ничу други манастири чији су ктитори били изван граница Ромејског царства. Године 980. Грузини подижу свој Ивирон, 985. Грци Ватопед, а убрзо затим Ксиропотам, Филотеј и Дохијар, Бугари свој Зограф, а нешто касније Руси свој Ксилург и св. Пантелејмон, у којем је св. Сава вероватно нашао своје прво духовно уточиште. Чак су и италијански бенедиктинци једно време (до XIII века) имали свој духовни кутак на Светој Гори. Већи број светогорских манастира, њих 20, дошао је до наших дана, али је не мали број њихов нестао током бурних векова средњовековља.

Непроцењиво материјално и духовно богатство, и поред свих пљачки и отимачина којима су били изложени светогорски манастири, сачувано је у прастарим здањима ове изразито духовне државе. Тек у последња два века почело је то непроцењиво богатство да израња из вишевековне скривености обасјавајући политичку и верску историју једног давно минулог времена о којем често немамо других извора ни података.

Још од свога настанка манастир Хиландар је постао главно духовно средиште српског народа и његових највиших духовних стремљења. Тај највиши духовни статус Хиландар је задржао до данашњих дана. И у светогорској духовној хијерархији Хиландар заузима високо четврто место, одмах после Велике Лавре, Ватопеда и грузијског Ивирона, ${ }^{2}$ уз напомену да су сви они по времену постанка старији од нашег светилишта. Високо место Хиландар на светогорској лествици свакако дугује не само зрачењу своје духовности већ и чињеници да су његови ктитори били један истакнути владар и светогорски дародавац Стефан Немања, у монаштву Симеон, и његов најмлађи син св. Сава чији је светачки култ веома поштован код већине православних народа.

Иако су многе појединости из многостране делатности манастира Хиландара током његовог 800-годишњег постојања избрисане из његових архива и усмене свести, ипак се може утврдити да његови становници нису увек били искључиво српског рода. Било их је разних националности, али изгледа највише из осталих словенских поднебља. Хиландар их је привлачио како својом материјално обезбеђеном егзистенцијом

${ }^{1}$ П. Поповић, Југословенска књижевност око средине ХІІ века, Годишњица Николе Чупића, књига LXVI, Београд, 1937, 120-121; Д. Богдановић, В. J. Ђурић, Дејан Медаковић, Хиландар, Београд, 1978, 24-26 (са најважнијом литературом).

2 Зоран Петровић, Манастири Свете Горе, Приштина, 1994. 
тако и својом моћном духовношћу, у погледу чега наш манастир није уступао примат чак ни византијским манастирима. У материјалном погледу Хиландар је и данас најбогатији светогорски објекат, а у средњем веку сви српски владари су као своју обавезу сматрали да треба да богато обдарују Немањину и Савину задужбину. О високој духовности српских светогорских монаха сведочи чињеница да је већина српских архиепископа и патријарха долазила из хиландарске средине. Манастир је био нека врста српског духовног универзитета који је својим члановима давао праву и највишу православну духовност.

\section{Хиландар и Русија}

Историја повезаности манастира Хиландара са огромним руским православним простором је истовремено и историја повезаности и прожимања ових двеју великих православних словенских култура. Разуме се по себи да манастир Хиландар није био једини чинилац који је спајао Србе и Русе. Генерално узето та међусобна православна струјања између два словенска народа ишла су преко два правца: један је био светогорски и хиландарски, а други је ишао од средњовековне Србије па преко православних несловенских земаља Влашке и Молдавије и допирао до Русије. ${ }^{3}$ Први је свакако био старији, формиран у XIII веку, а други је био познији и настао је после косовске битке и битке на Куликовом пољу 1380. године. Први правац српско-руских веза био је успорен пропашћу руске државе под ударом дивљих хорди Џингис-хана и његовог унука Батија чије су последице по Русију трајале више од једног и по века. О тој повезаности старе српске књижевности са руском имамо непосредних доказа у делу великог српског писца и Савиног ученика Доментијана. Почетком овога века руски научник М. Петровски ${ }^{4}$ је утврдио да је познати српски пи-

${ }^{3}$ Из врло опширне литературе о српско-руским културним односима наводимо: В. Мошин, О периодизации русско-южнославянских литературньх связей $X-X V$ вв, Труды отдела древнерусской литературы (даље ТОДРЛ) XIX, Москва-Ленинград, 1963, 23-107; Г. И. Вздорнов, Роль славянских монастырскихмастерских письма Константинополя и Абона в развитии книгописания и художественного обормления русских рукописей на рубеже XIV-XV вв., ТОДРЛ XXIII, 1968, 171-198; Д. С. Лихачев, Развитие русской литературы X-XVII веков, Ленинград, 1973.

${ }^{4}$ М. П.[етровский], Иларион митрополит Киевский и Доментиан иеромонах Хиландарский, Известия Отделения русского языка и словесности XIII/4, Москва, 1908, 81-133. 
сац унео у своје дело похвалу Владимиру из дела кијевског митрополита Илариона. ${ }^{5}$ Колико је из врло оскудних података о овом српском писцу познато Доментијан никада није боравио на руском тлу, па је логична претпоставка да је дело истакнутог руског писца кијевске Русије XI упознао на Светој Гори. Да ли је св. Сава познавао Иларионово дело остаје да се нагађа, али Иларионов утицај на Доментијана указује на литерарну и духовну повезаност између старе руске и старе српске књижевности, и то баш у светогорској и хиландарској средини.

Одсудна куликовска битка Руса под Димитријем Донским против татарског ига широм је отворила просторе за још чвршћу повезаност два словенска православна народа. Девет година касније одиграла се за Србе косовска битка са последицама равним куликовској, али у обрнутом смислу. Док је куликовска битка водила Русе у слободу и напредак, дотле је косовска битка за Србе значила не само губитак националне слободе већ и западање у стање безнађа које је водило скоро до духовне летаргије. Треба ипак подсетити да је српски светогорски духовни утицај на Русе био свакако доста јак и пре косовске битке. Цар Душан се прихватио ктиторства манастира руског св. Пантелејмона поставивши за његовог игумана светогорског монаха са Косова инока Исаију, ${ }^{6}$ чувеног преводиоца Псеудо-Дионисија Ареопагита, који је сав одгајан у духу светогорских и хиландарских традиција. После косовске битке незнани и знани српски пребези су бежећи од Турака одлазили у Русију преносећи и српске литерарне традиције. Али још пре косовске битке, после 1387, када су Турци заузели Свету Гору дошло је до егзодуса православних житеља Свете Горе у тражењу сигурнијег и безбеднијег простора за своје деловање.

Период краја XIV и XV века познат је у руској науци као тзв. „други јужнословенски утицај", ${ }^{7}$ који је стару руску књижевност упутио новим

${ }^{5}$ Похвала Владимиру је саставни део дела митрополита кијевског Илариона: Слово о законе и благодати, у чијем се наслову налази навод да садржи и похвалу Владимиру. Најновије критичко издање Иларионовог дела дао је А. М. Молдован, „Слово о законе и благодати” Илариона, АН СССР и АН УСССР, Киев, 1984.

6 Ђ. Трифуновић, Писаи, и преводилаи инок Исаија, Крушевац, 1980, (са литературом).

7 А. С. Орлов, Древняя русская титература XI-XVI вв., Москва-Ленинград, 1937, 234-243; Д. С. Лихачев, Литература времени национального подъема, предговор КњИЗИ ПАМЯТНИКИ ЛИТЕРАТУРЫ ДРЕВНЕИ РУСИ, XIV - средина XV века, Москва, 1981, 5-26; такође и у књизи истог аутора, Развитие..., стр. 83. 
путевима трасираним на Балканском полуострву и посебно у српској средини. Под српским утицајем у Русији настају нови литерарни жанрови, појављују се нови стилски изрази који су настали управо у хиландарској духовној средини. Још давне 1937. године истакнути историчар старе руске књижевности А. С. Орлов ${ }^{8}$ је тврдио да су најзначајнији српски писци постали познати у Русији још у XV веку. У ово наше време корифеј руске медиевистике Димитрије Сергејевич Лихачов је потврдио констатације А. С. Орлова, истакавши да су у XV веку била позната дела Немањиних синова, архиепископа Данила II и Константина Филозофа. Овде ћемо навести један карактеристичан пример: Волоколамски зборник бр. 208(620) садржи следеће текстове: Житије св. Саве од Теодосија, Похвалу св. Симеону Немағи и св. Сави од истог писца, Живот деспота Стефбана Лазаревића од Константина Филозофа и Живот Стефана Дечанског од Григорија Цамблака. ${ }^{9}$ Као што се види, читав зборник садржи само дела српских аутора у рускословенској редакцији, што значи да су у руској средини нашли своје верне читаоце. А таквих примера има још врло много.

Један несумњиво српски писац са светогорског простора, можда из самог Хиландара, Пахомије Логотет ${ }^{10}$ или Пахомије Србин, како га често зову, стекао је једно од највећих имена у старој руској књижевности. Оскудни биографски подаци не дају поуздане податке о евентуалној његовој делатности на српском тлу, али нико не спори да је у руску књижевност унео нешто од српских литерарних схватања и литерарних форми.

Један од најзначајнијих дарова старе српске књижевности је стилски манир који је у руској науци познат као „плетеније словес". Још пре више од три деценије Малик Мулић ${ }^{11}$ је показао да тај у Русији присутни стил XV-XVI века потиче са српског тла. Његови најранији прота-

8 А. С. Орлов, Нав. дело.

9 На Волоколамске преписе упутио ме је J. К. Бегунов, па му и овом приликом срдачно захваљујем.

10 Из врло опширне литературе о П. Логотету издвајамо: В. Яблонский, Пахомий Серб и его агиографические писания, С. Петербург, 1908; Г. Орлов, Пахомије Србин и юегова књижевна делатност у Великом Новгороду, Прилози КЈИФ, XXXVI, св. 3-4, Београд, 1970, 214-239.

11 M. Mulić, Srpsko „pletenije sloves” do XIV stoljeća, Radovi Zavoda za slavensku filologiju br. 5; Isti, Srpski izvori „pletenija sloves”, Zagreb, 1963; Исти, Сербские агиографи ХІІІ-XIV вв. и особености их стиля, ТОДРЛ ХХІІІ 1968, 127-142; Д. С. Лихачев, Монументально-исторический стиль древнеславянских литераmур, Славянские литературы, VIII Международный съезд славистов, Загреб-Юбляна, сентябрь 1978, Москва, 1978, 119-150. 
гонисти били су Доментијан, Теодосије, архиепископ Данило II и његов анонимни ученик, дакле све сами светогорски и хиландарски изданци. Последњи од њих, Данилов ученик, дао је и име том стилистичком изразу. У свом Житију Стефана Дечанског, у теолошком уводу каже да неће писати „сьплетениємь вътинскынми словесы” већ уз помоћ божје премудрости. Иако је желео да се у стилском погледу дистанцира од својих литерарних претходника, ипак их није сасвим напустио.

Неколико руских аутора је указало на могућу повезаност Даниловог зборника и једног споменика старе руске књижевности XVI века познатог као Степенная книга. Настао је у кругу митрополита руског Макарија, творца огромног зборника од дванаест књига тзв. Четыи минеи. Између 1560. и 1563, саставио је зборник Степенная книга који по структури доста подсећа на Данилов зборник. А. С. Орлов доста опрезно каже: „... а Цароставник” или „Родослов”, вероятно послужил в XVI в. для композиции подобного житийно-генеалогического сборника - „Степенной книги" московского митрополита Макария." 12 Доиста, када прочитамо само врло дуги наслов те књиге ${ }^{13}$ уочавамо да он, мада знатно проширен у односу на наслов Даниловог дела, знатно на њега подсећа. Ваља подсе-

12 А. С. Орлов, Нав. дело, 235. Као што је српски архиепископ Данило II желео да напише похвална житија српских владара и архиепископа такав исти циљ себи поставио је митрополит Макарије.

${ }^{13}$ Пуни наслов, према А. С. Орлову, стр. 335. гласи: „Книга степенна царского родословия, иже рустей земли в благочестии просиявших богоутвержденних скиптеродержителей, иже бяху от бога, яко райская древеса насаждении при исходищих вод, и правоьерием напаяеми, благоразумием же и благодатию возрастаеми и божественной славою осияваеми явишася, яко сад доброраслен и красен листвиеми благоцветущ, многоплоден же и зрел, благоухания исполнен, велик же и высоковерх и многочадным рождением, якосветлозрачными ветвми расширям, благоугодными добродетельми преуспеваем. И мнози от корени и от ветвей многообразными подвиги, яко златными степенми на небо восходную лествицу непоколеблему воздружиша, по ней же невозбранен к богу восход утвердиша себе же и сущим по них." Као и Данило II и Макарије жели да глорификује не само владаре и моћнике већ и духовна лица. Макарије, местимице идући за старим руским летописима, супротно од нашег Данила II наводи неке поступке велможа у којима више има грубости па и бестијалности него хришћанске побожности. Ј. С. Лурје (История русской литературы, том первый, Ленинград, 1980, стр. 257-258) упућује „романтични” карактер љубавне приче о Јурију Свјатославовичу Смоленском који је занет преступном љубави према Уљани Вјаземској ову убио, а после тога у знак покајања се замонашио, умро и сахрањен уз „погребна пјенија”. Примере такве врсте избегава археипископ Данило II (Милутинов пример.) 
тити да дуги наслов Даниловог зборника није одлика само појединих његових преписа. Најстарији препис Даниловог дела, Сопоћански зборник попа Дмитра из 1526. године ${ }_{1}^{14}$ нешто различит у односу на друге млађе преписе, такође је врло дуг. Оскудни биографски подаци о митрополиту Макарију и његовом митрополитском наследнику Андреју не кажу да ли су претходник и следбеник боравили на Светој Гори, па тако не знамо да ли су Данилово дело упознали на руском простору или на Светој Гори. Данилов зборник је делом настао вероватно у Србији а делом у светогорској хиландарској средини. Данас се обично узима да је завршни облик Даниловом зборнику дао његов анонимни ученик-светогорац. Најстарији препис Даниловог зборника који се налазио у Хиландару преписан je 1553. године ${ }^{15}$ у манастиру Милешеви па није немогућа претпоставка да је тај препис на неки начин дошао до митрополита Макарија послуживши му као узор.

Око средине XVI века на територији Русије стекао је доста важан култ св. Сава Крипецки. Канонизован је у светитеља тек средином XVI века иако се преставио још 1495. године. ${ }^{16}$ У његовом житију написаном после посвећења стоји да је био пореклом Србин и Хиландарац. Иако нам неке битне појединости из његовог живота недостају, ипак се може претпоставити да су обе тврдње - да је био Србин пореклом, а Хиландарац по животном опредељењу - тачне. Из српског светогорског манастира прешао је у Русију у Псков где је стекао велики углед.

Утицај Хиландараца на руски дух био је нарочито јак за владе руског цара Ивана Грозног. Његова баба била је пореклом од српских Јакшића. Оставши рано без родитеља, будући руски цар био је под снажним утицајем своје бабе, књегиње Ане Глинске-Јакшић која је свом унуку улила велику љубав према српском роду и Хиландарцима. Резултат Иванове оданости Хиландару јесте и раскошна катапетазма коју је подарио српском светилишту. ${ }^{17}$ Уопште, епоха Ивана Грозног обележена је снажним утицајем Хиландараца и неговањем култа првог српског архиепископа.

14 Д. Петровић, Дела архиепископа Данила II у Сопоћанском зборнику из 1526. 2., зборник АРХИЕПИСКОП ДАНИЛО ІІ И ЊЕГОВО ДОБА, САНУ Београд, 1991, стр. 203-209.

15 Д. Богдановић, Каталог ћирилских рукописа манастира Хиландара, Београд, 1978, стр. 167. У међувремену препис је пронађен. Сада се чува у Архиву САНУ у Београду, регистрован под бр. 14509.

16 С. Петковић, Свети Сава Српски у старом руском, румунском и бугарском сликарству, у књ. Сава Неманић - Свети Сава: историја и предағее, САНУ, Београд, 1979, стр. 367-368.

${ }_{17}$ Иcmo. 


\section{Хиландар и Бугарска}

Географски и политички најближа култура старој српској јесте бугарска цивилизација. Вековима су те културе биле чврсто повезане међу собом. Државне границе двају балканских суседа често су мењане, па је тако граница државе Стефана Дечанског и његовог сина Душана залазила и у садашњу територију Бугарске. Обновљена Пећка патријаршија 1557. године је обухватала не мале просторе бугарске државе, док је у територијалном смислу Бугарска делила судбину свога западног суседа, Србије, пошто су обе вековима улазиле у састав Отоманског царства. То значи да су оба балканска народа била у непрекидном духовном контакту. То значи, даље, да су духовна стремљења Срба и Бугара била слична, али су различите литерарне и културне традиције водиле ка неким облицима дивергенције.

Број Бугара, који су своје животно опредељење везали за манастир Хиландар у средњем веку, био је свакако већи него што се може закључити из штурих архивских података. Међу оним Бугарима који су боравили у Хиландару истакнуто место заузима будући српски патријарх Јефрем. Тек у наше време заслужни Димитрије Богдановић ${ }^{18}$ утврдио је његов идентитет и замашно књижевно дело. Из до нас доспелих извора види се да је овај писац бугарског порекла боравио у манастиру Хиландару између 1335. и 1347. године када је дошао у Србију и настанио се у околини Пећи. Аскетски опредељен, Јефрем је у два наврата био на челу српске цркве - 1375-79. и 1389-92. када је дефинитивно напустио кормило српске цркве. Умро је 1400. Не знамо прави узрок његовог боравка у Хиландару, али највероватнија изгледа претпоставка да га је српско светилиште привукло својом духовношћу.

Током XVII-XVIII века манастир Хиландар је био настањен монасима углавном бугарске националности. Бугарски научник J. Иванов ${ }^{19}$ присутност Бугара у српском манастиру објашњава чињеницом што је Света Гора територијално знатно била ближа Бугарима него Србима. У незаобилазној књизи бугарског научника налазимо више података о присутности Бугара у манастиру Хиландару, нарочито у XVIII веку. Хиландар је добијао дарове од побожних Бугара, што сведочи о високом угледу који је уживао код Бугара српски манастир. И много раније Бугари су налазили место за своју делатност у Хиландару. Још у XV веку неки Бу-

${ }_{18}$ Шест nuсаца XIV века, Избор, данашња језичка верзија и редакција проф. др Д. Богдановић, Београд, 1986, 38-41, 99-161 (са литературом).

19 Й. Иванов, Български старини из Македония, София, 1931, 264-274. 
гарин Герасим преписао је један зборник за деспота Стефана Лазаревића (сада у Одеси). Неки хаџи Влчо из Банског осликао је својим средствима параклис Јована Рилског у Хиландару. Године 1757. неки Данило, проигуман манастира Хиландара, преписао је у Ловечу Амартулон Сотириа.

Два вероватно најзначајнија бугарска литерарна посленика новијег доба који су своју животну судбину везали за Хиландар су Пајсије Хиландарски и Јосиф Хиландарски, обојица из XVIII века. За првог познати бугарски књижевни историчар Бојан Пенев ${ }^{20}$ тврди да је „био прва крупна личност која је својим делом История славянобългарска желео да пробуди бугарски национални дух". Пајсије је живо осећао несрећу свога народа због чега је написао своју Историју. Пајсије је не мали део свога живота провео међу Србима, па га налазимо чак у Сремским Карловцима. У манастиру Хиландару Пајсије је био у прилици да упозна најновија духовна стремљења која је међу светогорцима ширио Грк Евгеније Вулгарис, ${ }^{21}$ човек универзалног образовања, упућен у филозофију и теологију. Своје дело Пајсије није писао само на основу самосталних научних истраживања. Главни извор за његово дело била је књига Мавра Орбина Краљевство Словена у којем је доста простора посвећено историји Бугара. Дуговање свом извору признаје сам Пајсије. Супротно Ј. Иванову, руски путник Пајсијевог доба Василије Григорович Барски ${ }^{22}$ пише да су хиландарски монаси Срби, тврди у вери и јаки у савлађивању незгода, па су најгостопримљивији, али су прости и необразовани. Скоро два века касније Ј. Иванов тврди: „За турског ропства Хиландар је мало-помало губио свој српски вид и постао бугарски".

Други Бугарин кога је у XVIII веку привукла хиландарска средина био је Јосиф Хиландарски. ${ }^{23}$ Од њега је остало једно дело необичног али за нас значајног садржаја. Дело има аутобиографских примеса, али је најзначајније у садржају то што аутор поучава о потреби читања и о начину на који се то чини.

Са Хиландарцима Пајсијем и Јосифом улазимо у ново време када је аутентични дух средњега века нестао и почео да се замењује духом новога времена. То није предмет нашег истраживања.

20 Б. Пенев, Пайсий Хилендарски, София, 1946, 11.

${ }^{21}$ Исто, 14.

${ }_{22}$ Навод према Х. Христов, Пасиий Хиландарски, неговото време, жизен път и дело, София, 1972, 17, 19.

${ }_{23}$ П. Динеков, К. Куев, Д. Петканова, Христоматия по старобългарска литература, второ подобрено издание, София, 1967, 515-518. 
Још једна словенска књижевност - украјинска - делимично само везана је за духовну сферу манастира Хиландара. Украјинци нису били под утицајем хиландарске духовне климе као што је то био случај са Бугарима и још више са Русима. У науци је познато неколико Украјинаца ${ }^{24}$ који су своје дело уградили у манастир Хиландар и у српску књижевност. Најзначајнији од њих су Гаврило Мсиславич (умро 1508. г.) и Самуило Бакачић (XVII век), ${ }^{25}$ за кога не можемо са сигурношћу тврдити да ли је Украјинац или Рус. Зна се да је био јеромонах и да је боравио у Хиландару. На измаку XVII века Бакачић преводи више дела са руског и грчког језика на српски, од којих је најпознатије и најутицајније Амартолон сотириа (Грешних спасение) Агапија Ландоса. Преводилачка делатност С. Бакачића показује да духовна активност у манастиру Хиландару није била прекинута и поред изузетно тешких прилика у којима се налазио наш манастир и цела Света Гора.

Ова скица о Хиландару као важном духовном жаришту међу православним словенским народима као превасходни циљ има да покаже вишевековну његову духовну присутност. Више него друга словенска светогорска светилишта наш манастир је привлачио православце и не само словенске. Сви они који су као животни циљ желели да постигну више сфере духовности могли су да их нађу у Хиландару, без обзира на њихову националну припадност. Хиландар је у много чему остао у духовном смислу екстериторијалан простор као што је то била и цела Света Гора.

\section{Damnjan Petrović}

\section{MONASTERE HILANDAR - FOYER DE LA CULTURE SLAVE ORTHODOXE Résumé}

Dans ce travail nous avons traité le rôle spirituel du monastère Hilandar ainsi que son influence sur les peuples slaves orthodoxes. Dans ce monastère serbe situé dans la zone du Mont Athos jouissant des prérogatives d'exterritorialité se rendirent souvent les ecclésiastiques de tous les pays slaves qui contribuèrent à la pro-

24 Ђ. Сп. Радојичић, Стари српски писци украјинске народности (од краја XV до краја XVII века), Годишњак Филозофског факултета у Новом Саду, V, 1960, 199-218.

25 Исто, 204-216 (са наведеном старијом литературом). 
pagation de son influence orthodoxe et littéraire. En tant qu'un fait reconnu, nous soulignons que ce monastère fut aidé par les nombreux souverains et les seigneurs orthodoxes à l'époque de la domination turque. Une attention particulière est prêtée à l'examen de l'influence du monastère Hilandar sur les Russes, les Bulgares et les Ukrainiens. 